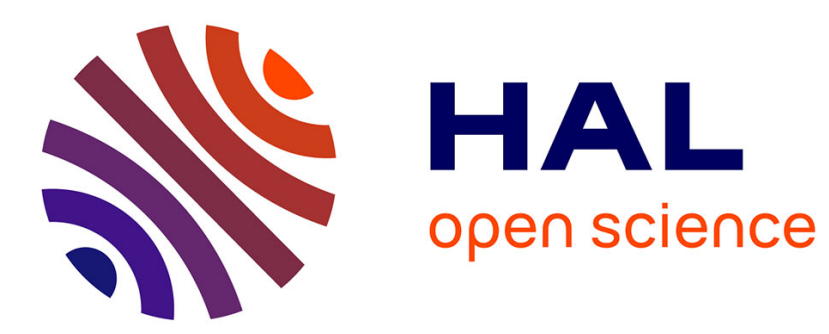

\title{
Corporate social responsibility and management control
}

Alexander Mersereau, Nicolas Mottis

\section{To cite this version:}

Alexander Mersereau, Nicolas Mottis. Corporate social responsibility and management control. 2011, pp.39. hal-00661041

\section{HAL Id: hal-00661041 \\ https://essec.hal.science/hal-00661041}

Submitted on 18 Jan 2012

HAL is a multi-disciplinary open access archive for the deposit and dissemination of scientific research documents, whether they are published or not. The documents may come from teaching and research institutions in France or abroad, or from public or private research centers.
L'archive ouverte pluridisciplinaire HAL, est destinée au dépôt et à la diffusion de documents scientifiques de niveau recherche, publiés ou non, émanant des établissements d'enseignement et de recherche français ou étrangers, des laboratoires publics ou privés. 


\section{Corporate social responsibility and management control}

\section{Research Center \\ ESSEC Working Paper 1114}

2011

Alexander Mersereau

Nicolas Mottis 


\title{
CORPORATE SOCIAL RESPONSIBILITY AND MANAGEMENT CONTROL
}

\author{
Alexander Mersereau \\ Associate Professor \\ HEC Montréal \\ 3000 Chemin de la Côte St Catherine, \\ Montréal, CANADA \\ H3T $2 \mathrm{~A} 7$ \\ Canada \\ E-mail: alexander.mersereau@hec.ca
}

\author{
Nicolas Mottis \\ Professor \\ ESSEC Business School \\ Avenue Bernard Hirsch \\ BP105 \\ 95021 Cergy Pontoise cedex, \\ France \\ E-mail: mottis@essec.fr
}

\begin{abstract}
This paper focuses on the management control processes associated with Corporate Social Responsibility (CSR) issues management in organisations. Following a review of the literature related to management control and CSR, we use a case example of a leading European insurance company to explore the extent and nature of management control for CSR.

Cet article porte sur les processus de contrôle de gestion liés au management des performances RSE dans les organisations. Suite à une revue de littérature, une étude de cas d'une compagnie d'assurance leader en Europe est développée pour illustrer les enjeux pratiques et théoriques du contrôle de gestion dans ce domaine.
\end{abstract}

\section{Keywords}

CSR - Management control

RSE - Contrôle de gestion

JEL Classification: M14, M1 


\section{Biographical note}

Alexander Mersereau is an Associate Professor in the Accounting Department at HEC Montreal and a Certified Management Accountant. His principle areas of interest are cost management, the development and use of organisational performance measures, the influence of strategy on accounting systems and the evolving roles of the accounting and control functions. He is the co-author of a textbook on management accounting and has published articles in the field. In addition to his academic appointments, he is active as a consultant and lecturer in executive development programs.

Nicolas Mottis is management control professor at ESSEC Business School in France. His research areas focus on strategic control (corporate governance, value creation, socially responsible investment, incentives and performance measurement) and project management in high tech sectors (information systems, automobile, and biotech). He has published many articles and several books on these subjects. He also works as a consultant for companies on strategic control and project management issues. 


\begin{abstract}
This paper focuses on the management control processes associated with Corporate Social Responsibility (CSR) reporting in economic organisations. Existing research yields a polarised picture of CSR. Some research takes the position that organisational commitment to CSR goals is strong and enacted programs have yielded positive results. Other research concludes that the primary objective of CSR reporting is the enhancement of corporate image, rather than affecting real change.
\end{abstract}

This paper takes the perspective that commitment to CSR can be understood by looking at the management control systems that are created to in support of CSR reports. We predict that organisations wishing to enact CSR related change will also implement corresponding management controls. Following a review of the literature related to management control and CSR, we use a case example of a leading European insurance company to explore the extent and nature of management control for CSR. To date few papers have examined this connection and a principle contribution is the documentation of specific elements related to the controls implemented. The study provides an example of an organisation that has used management control mechanisms intensively to achieve initial successful results. However questions are raised over the ability of the organisation to continue this pace.. 


\section{CORPORATE SOCIAL RESPONSIBILITY AND MANAGEMENT CONTROL}

\section{INTRODUCTION}

Profit seeking corporations are increasingly disclosing information related to the impact of their activities on the physical environment and on society. The most cited survey of corporate social responsibility (CSR) or sustainability reporting is probably the tri-annual International Survey on Corporate Responsibility Reporting prepared by the accounting / consulting firm KPMG and last published in 2008. This latest report shows that $74 \%$ the top 100 US companies published corporate responsibility information in 2008 , as did $80 \%$ of the top 250 corporations worldwide.

Since most of CSR reporting is unregulated and organizations affect the social and physical environment in different ways, it is natural that differences arise in the content and the approach taken to corporate social responsibility disclosure. For example Chen and Bouvain (2008), examining CSR reporting in four countries (US, UK, Australia, and Germany), finds significant nationality influence on the extent and content of CSR reporting. Henri and Journault (2008) finds CSR reporting to be influenced by other characteristics, including size and public ownership.

Nevertheless some standardization seems to be occurring. The most commonly used framework is the Global Reporting Initiative's (GRI) Sustainability Reporting Guidelines The body responsible for GRI, Coalition of Environmentally Responsible Economies (CERES), reports that over 1100 reports were officially registered with them in 2009 
(Sherman and Di Guilio, 2010). The 2008 KPMG study also found that almost all of the G250 companies surveyed relied on the GRI guidelines as the basis for compiling their CSR disclosures.

An important question is the extent to which increased sustainability reporting is matched by increased efforts by organisations to achieve change. Do some organisations simply choose to disclose information on their social and environmental performance while others actively change work practices in conjunction with disclosure? For many organisations improving sustainability may make good business sense. Some activities that reduce environmental waste may also reduce cost. Programs to improve working conditions of employees may also improve productivity and motivation.

A useful lens to examine CSR activities is through the perspective of management control. This field is specifically interested in the mechanisms used to execute strategy. Understanding whether controls have been created to support environmental and social strategies and how those controls are used can yield a better understanding of the strategic intention of sustainability initiatives.

\section{CSR and the financial sector}

The financial services sector covers a wide range of activities, including retail and commercial banking, property insurance and life assurance. Compared to other sectors, such as manufacturing or pulp and paper, the financial services sector has 
much lower direct environmental impact. Nevertheless financial institutions do create waste and consume significant amounts of resources, specifically paper and energy. Financial institutions also employ large numbers of people and typically have large numbers of stakeholders. In addition the financial sector is a facilitator of industrial activity. The insurance sector also is very involved with the risks associated with environmental and social issues through the products they provide.

It is evident from published information that some CSR activity has been occurring in this sector. A number of banks have come together as signatories to the "Equator Principles", voluntary guidelines for managing social and environmental issues related to the financing of development projects. Some financial institutions restrict part of their investment funds to companies that meet certain sustainability hurdles.

In this paper we will first look at the published academic literature covering the application of management control to sustainability strategy. We will then look in depth at the case example of Crédit Agricole Assurances, a French insurer and part of Crédit Agricole, one of the largest financial institutions in Europe.

\section{Management control theory}

A fundamental challenge for management control is aligning people and other resources to the goals of the organisations. Anthony (1988) defined management control as a process by which managers influence other members of the organisation to implement the organisation's strategies. Simons (1987) defined the management 
control system as formalized procedures and systems that use information to maintain or alter patterns in an organizational activity. We can think of an organisation as having an overall control system that is itself composed of numerous other control systems. Control and strategy are interlinked. Without control systems, strategy is unlikely to become realised. In the absence of strategy (objectives) control has no purpose.

One of the more cited frameworks for understanding control is that of Simons (1995) in which control is seen to be accomplished through a series of four levers: belief systems, boundary systems, diagnostic control systems and interactive control systems. The first of these control levels, boundary systems, refers to the "the acceptable domain of strategic activity for organizational participants" (Simons, 1995). The notion of boundary systems includes a range of elements used to limit behaviour within an organization such as organizational structure, physical constraints, rules and policies. With respect to CSR, boundary systems might include assigning specific environmental roles and tasks, establishing regulations on how waste is to be treated and policies against workplace discrimination or policies on purchasing.

The notion of belief systems refers to the values and codes of conduct that guide behaviour and decisions of organisational members. Simons (1995) defines a belief system as "the explicit set of organizational definitions that senior managers communicate formally and reinforce systematically to provide basic values, purpose, and direction for the organization". Management can affect belief systems through 
published communications such as mission statements and values statements and through personal example.

The last two levers of the Simons model, diagnostic control systems and interactive control systems, both refer to performance measures. Diagnostic control systems involve measures that cover the breadth of an organisation's strategic environment. The factors that are monitored by diagnostic systems are important; however outcomes can be predicted with some certainty and significant change is infrequent. On the other hand, the interactive use of performance measures refers to the exceptional use of a small number of measures that inform management on the factors that are currently influencing strategic success. Interactive use implies frequent discussion of measurement results and constant challenge and debate over the relevance, reliability and meaning of each measure. The measures from the interactive control system evolve permanently.

An important measurement concept in management control is the idea that managers should pay attention not only to the outcomes and consequences of their actions but to the factors that affect the probability of success of their actions. To this end, the balanced scorecard framework (Kaplan and Norton, 1992) proposes that managers should measure, in addition to strategic outcomes, the drivers of these outcomes. These measures are most often used interactively. 
In order to examine the connection between sustainability and control we will first look at the published literature to determine the extent to which the following factors are discussed:

- The extent to which management control literature discusses CSR and vice versa

- The extent to which specific CSR structures have been created

- Rules policies and other constraints related to CSR

- CSR performance measures used by managers

- How these measures are used: the frequency which measures are produced and discussed, whether targets are set, and whether incentive rewards are attached

\section{Literature on sustainability control}

Management control literature has speculated on the existence of control systems specifically designed to promote sustainability goals. Three related concepts have been discussed; environmental management accounting (EMA), eco-control and environmental management systems. Ferreira et al. (2010) defines EMA as "a technique that generates, analyses and uses both financial and non-financial information to improve the environmental and economic performance of a company, and contributes towards a sustainable business". Henri and Journeault (2010) positions eco-control as part of EMA, defined as "the formalized procedures and systems that use financial and ecological information to maintain or alter patterns in environmental activity". Eco-control is seen to be composed of three practices: the use of 
performance measures by managers, budgeting and incentives. Melnyk et al. (2003) uses the term "environmental management systems". Although they do not define the term specifically the concept includes environmental performance measurement and environmental auditing.

The common element in these definitions is that management control systems can be used for executing a sustainability strategy. However none of the above terms are particularly well suited since the focus on environment is too restrictive. Therefore for the purposes of this article we shall use the term sustainability control systems to refer to management control systems that include various control mechanisms with the goal of implementing sustainability strategy.

There are few large sample studies that have directly examined management control and sustainability. The closest we find is Yin and Schmeidler (2009) that looked at ISO 14001 certification and found that about $40 \%$ of the applying facilities had integrated sustainability practices into their daily operations. Integration is defined here as participation in planning and use in daily routines, however the respondents were not requested to provide details. The study also found significant variations in the degree to which employees participated in ISO application process and the extent to which metrics were refined, targets were set and metrics were used to reinforce commitment. 
Only a few normative papers discuss the implementation of formal sustainability control systems. Melnyk et al. (2003) speculates that organizations receiving certification under the ISO environmental management standards will have accomplished the following due to the ISO 14001 evaluation criteria:

- Management and employee commitment to the protection of the environment, with clear assignation of accountability and responsibility,

- An environmental policy appropriate to the organization,

- A program to implement these policies with a disciplined process of evaluating and achieving target performance levels,

- Environmental planning encouraged throughout the full range of the organization's activities,

- The provision of adequate resources, including training, to achieve targeted performance levels.

Epstein and Roy (2001) proposes that organisations should adopt a balanced scorecard approach to CSR and adopt measures of the internal drivers of externally reported information. These drivers would include, for example, work force diversity, environmental impact, community involvement and human rights. Ilinitch et al. (1998) recommends redesigning cost estimation systems with an environmental focus.

The largest body of published empirical research is case research. Case research examines a range of sustainability activities, including projects to reduce the energy use and other forms of waste, product redesign and worker safety and other training 
programs. This literature yields a partial picture of management control processes attached to these activities.

With respect to boundary systems, most of the published case studies refer to elements of organisational structure. Riccaboni and Leone (2009), for example, observes the creation of a centralised sustainability department and the creation of special roles (sustainability ambassadors). Humphreys and Brown (2007) observes the creation of a new position termed "head of CSR" as well as the creation of an employee community committee. Morsing and Oswald (2009) report on the creation of a Stakeholder Relations function within a Danish health care company, which has significant responsibilities including CSR. Albeda Perez et al. (2007) finds operational level environmental management committees in four (out of ten) organizations studied. Masanet-Llodra (2006) reports on the conversion of the quality manager role into that of an environmental and quality manager.

Rules seem to play a minor role in corporate social control systems in published case research. Several studies speak of the creation of a CSR policies and codes of practice relating to purchasing (Keating et al., 2008; Spence and Bourlakis, 2009; Andersen, 2003). Norris and O'Dwyer (2004) compares formal and informal control systems in a retailer but does not discuss boundary systems at all.

With respect to belief systems, a dominant theme in case literature is the efforts to shape employee involvement in CSR. Riccaboni and Leone (2009), looking at Procter 
and Gamble, identify a variety of programs including the publication of a quarterly sustainability newsletter for employees, the designation of an "earth day" each year and intensive internal top management communication on sustainability. Specific CSR training programs are identified in several studies. Employees are sometimes surveyed (Andersen, 2003) and employee suggestions are sometimes sought (Morsing and Oswald, 2009; Albeda Perez et al., 2007). And as was previously mentioned, CSR values are reinforced by some organisations when they encourage employees to participate in community activities. On the other hand several studies note the absence of employee involvement in CSR planning and execution. Enquist et al. (2006) find that only top managers are involved in CSR reporting and that most employees are only vaguely aware of what sustainability reporting entails and its impact on their day-today operations. Durden (2008) found no evidence of shared values or collective beliefs related to CSR.

Case work reveals a varied picture on the development of CSR metrics, ranging from extensive metric design to none at all. Albeda Perez et al. (2007) reports on the design of an environmental scorecard used for control purposes. Riccaboni and Leone (2009) discusses the creation of a variety of financial (sales from sustainable products) and non-financial (CO2, waste energy, water use) metrics for managerial use. Burritt and Saka (2006) provides a series of six small case examples on sustainability management in Japanese companies, four of which discuss the creation of non-financial metrics for managerial decision making. Barandas et al. (2002) reports on the CSR program at the French company Areva and indicates the development of a large range of internal 
metrics. Morsing and Oswald (2009) provides a detailed list of CSR metrics that are used internally. Pederson and Neergard (2008) refers to the creation of several employee based metrics (satisfaction, the percentage of employees with special needs, health and safety) as well as a supplier metric.

On the contrary, other cases reveal very limited development of CSR metrics (Keating et al. 2008; Enquist et al. 2006). Some organizations claim to be in the process of developing indicators (Masanet-Llodra, 2006). And finally some cases reveal no interest in creating CSR metrics (Norris and O'Dwyer, 2004). Some explanation is offered. Adams \& McNicholas (2007) and Durden (2008) reports on the difficulties encountered in trying to design new CSR metrics. The use of CSR measures is sometimes discussed. Albeda Perez et al. (2007) observes CSR metrics discussed during management control meetings. Riccaboni and Leone (2009) reports the development of a sustainability assessment tool used to take product innovation decisions. Morsing and Oswald (2009) reports on the use of sustainability measures in assessing divisional performance. In one of the six sites examined by Burritt and Saka (2006) non-financial environmental indicators are used in assessing sub-unit performance.

Targets are an essential component of management control systems and are used when it is believed that managers have sufficient control over future results. In the Procter and Gamble case, Riccaboni and Leone (2009) reports that CSR targets were set for a wide range of business sub-units (divisions, departments, countries, teams and individuals). Barandas et al. (2002) speaks of setting objectives for the large set of 
CSR measures in use at Areva. Morsing and Oswald (2009) observe an organisation in which objectives are set for a large number of CSR categories, including diversity, talent development and environmental performance.

Some case studies reveal limited use of targets. Pederson and Neergard (2008) reports that targets were set for a small range of CSR areas including employment of people with special needs, emissions, electricity and water consumption. Enquist et al. (2006) speaks of targeting reductions in three environmental measures but no details are provided. Gates and Germain (2010) survey controllers in France and find that CSR metrics play only a minor role in organisational control. Norris and O'Dwyer (2004) remark on a lack of focus on CSR performance outcomes.

The literature reveals hardly any interest in connecting performance incentives to CSR metrics. Pederson and Neergard, 2008) observe a management reward systems linked to CSR performance to a limited extent; however details of even this connection are not provided. Norris and O'Dwyer (2004) observe that managers were rewarded exclusively on financial measures. Morsing and Oswald (2009) report finding no link between sustainability objectives and performance compensation.

In summary, published literature gives us some information on how control systems for sustainability might look. We know that structures are sometimes modified and employee engagement is often sought but we see little evidence of boundary controls. Internally used measures are sometimes created however we know little of the rigour 
of the targets, how or if they are connected to performance appraisal, the frequency that metrics are examined, or the processes used to improve metric design.

\section{Studies on financial institutions}

Only a few academic studies have specifically addressed the issue of sustainability within financial institutions. Using analysis made by two agencies, CERES and the Carbon Disclosure Project, Crawford and Williams (2010) finds that banks in countries with higher levels of mandatory disclosure, such as France, produce more quality disclosure than those in countries with lower levels of mandatory disclosure, such as the USA. The sample size however is small. Weber (2005) conducts a large scale study of publicly disclosed CSR information from European banks examining the level of integration of sustainability into their business strategies and practices. The study finds variations in reported results in some areas, including energy use per employee, gender equality, employee transportation and the integration of employees in the CSR decision process. The study also finds some discussion of program activity related to these results (for example programs to subsidize employee transportation). However there is no specific discussion of management control.

Several studies (Douglas et al., 2004, Branco \& Rodriguez, 2006; Cuesta-Gonzalez et al., 2006) have examined public disclosure from banks within specific countries. This research tends to focus on the volume of CSR disclosure rather than the practices that generate results. Of the previously cited case studies, three were conducted within the financial services sector (Enquist et al., 2006; Humphreys and Brown, 2007; Keating et 
al., 2008). While these studies provide a partial view of CSR control practices, the evidence is far too limited to permit generalisation.

\section{Research methodology}

We conducted a field study in a French insurance company Crédit Agricole Assurances, a part of Crédit Agricole S.A., one of the largest financial institutions in Europe. The goal of the study was to obtain an in-depth understanding of the sustainability efforts in that enterprise, with a particular focus on the performance measurement and management control aspects of a CSR strategy.

Field research is an increasingly used research methodology in management control. This research involves person to person contact between researchers and managers. Interviews are based on open ended questionnaires that permit the interviewer to examine a pre-determined theme and explore areas of interest that arise during the interview. Field research permits the collection of various types of evidence enabling researchers to validate information. A main contribution from field research is the identification of specific questions that can be examined either in future field studies on in large sample studies. While field research is strong in terms of internal validity, its main weakness is a potential lack of external validity. It is difficult to generalize from information gathered from a single site.

In this study interviews were conducted with three senior managers of the company. At Crédit Agricole Assurances (CAA) we interviewed, in their offices on two separate 
occasions, Brigitte Cachon, Director of Corporate Communications who is responsible for SER within CAA and Frédérique Boulanger a senior manager in the Sustainable Development department. We also interviewed Jérôme Courcier, Head of the Sustainable Development department at the Crédit Agricole S. A. (CASA) corporate office on two occasions. Interviews were lengthy, notes were taken and typed and the participants were open and informative. Further information was gathered from follow up telephone interviews and e-mail exchanges.

In addition to the field interviews, we reviewed CSR related documents from CASA and CAA. In this regard, we examined the published web site information on CSR activities at CAA and CASA, including all press releases and annual reports, a management presentation describing in detail measurement activities related to carbon (CO 2 and NO2) generation, and an employee oriented short movie on CSR.

\section{Managing sustainability at Crédit Agricole Assurances}

Crédit Agricole SA (CASA) is a cooperative bank based in Paris and operating in 70 countries. With a worldwide staff of 160,000 and $€ 71$ billion in equity, it is one of the largest banks in Europe. As the central bank in a network, CASA assures unity and coherence among its regional banks and designs the products and services they offer to their customers. CASA also manages a variety of subsidiaries in specialized lines such as insurance, asset management, consumer credit, leasing and investment banking. 
CASA is well ranked in several major sustainable development indexes and is a signatory to several important sustainability accords. In late 2007, the Group was named "Global Bank of the Year" by The Banker magazine for its socially and environmentally responsible policies. At the corporate level CASA manages an active and successful sustainable development program that encourages all subsidiaries to develop initiatives, measures and targets.

The CASA Insurance subsidiary is known as Crédit Agricole Assurances (CAA). Operating through a group of subsidiaries, CAA is a market leader in Europe in its three main areas of activity: personal insurance, general insurance and creditor insurance. CAA is not a traditional insurer, in that sales activities are carried out within the CASA bank branch network, rather than through agents working directly for CAA.

Involvement in sustainability management and reporting at CAA began with Bernard Michel who was appointed Chief Executive Officer of CAA in 2008. Mr. Michel held a personal commitment that CAA should make a substantial contribution to social and environmental improvement. Acting on this, his first step was to request a well established consultancy to complete a benchmarking study of CSR activity in the insurance sector in France. The main outcomes of the study were to confirm that CAA was not particularly behind others and to stimulate the company to action. 
The CAA sustainability strategy is based on four key axes: environment, human resources, products and services and solidarity. The general objectives established for each of the four axes are:

- The environment: limit direct and indirect impact on the environment

- Human resources: promote diversity as a signatory to the Diversity Charter

- Products and services: influence CAA customers' behaviour in terms of investment choices and lifestyles

- Solidarity: develop the company's and its employees' actions within the community

At CAA social and environmental responsibility (SER) is led by an oversight committee, chaired by the current CEO of the Crédit Agricole Assurances group, Jérôme Grivet, that includes SER officers from each of the six main CAA subsidiaries. This committee meets quarterly and validates the broad SER guidelines. Planning is made in two year blocks. The first of these, covering $2010-2012$, is nearing completion. The committee is supported by a network of around 35 SER correspondents, representing the main business lines of the Crédit Agricole Assurances subsidiaries as well as all of the main functions. This network meets regularly as a group however the main focus is on specific themes that are addressed by sub-committees of the main group. Sustainable development activities are managed by Brigitte Cachon, Director of Corporate communications who assumed responsibility for SER within CAA in January 2009. 
The cornerstone of the SER program is the belief that the program will only be successful if it belongs to the employees of the company. Brigitte Cachon explains the SER philosophy this way:

"This is both a top down and a bottom up approach. However the bottom up part represents $80 \%$ of the achievement. That is to say that $80 \%$ of what we achieve will be due to changes in people's attitudes towards these issues and $20 \%$ will be due to specific decisions made by management. One of our early initiatives was to look for some visible quick wins with the objective to convince employees of the feasibility of SER program".

This was followed by an awareness campaign that included a number of different activities:

- A corporate film, involving approximately 100 employees, was created to launch the SER programme and confirm management's commitment to it

- A poster campaign was initiated in the various insurance sites in France and abroad showing sustainable development correspondents and employees to demonstrate the group's commitment to the four key issues.

- A series of quarterly SER seminars was launched. The seminars are run on a voluntary basis and all employees are invited to attend. The seminars can be also downloaded from the internet.

- SER workshops run by experts are held frequently in order to make the subsidiaries aware of the SER issues that they face. Examples include a 
workshop on the use of paper for business lines that use a significant amount of paper (marketing and advertising, purchasing, etc.) and a climate change workshop for property \& casualty actuaries.

- Regular communications are made to employees via an on-line newsletter.

Management also created a series of performance measures in order to track and manage environmental performance. Specifically thirteen key measures were selected (See table 1) covering all four axes. For most measures, short term targets were set. The goal of these targets was twofold. In the first place, the targets set challenging goals in order to assure progress. But the targets also provide an orientation for the wider range of CSR activities, ensuring that people are all focused on the same things.

Insert table 1 around here

Measurement frequency varies significantly. For example the measures related to the human resources axe are taken monthly and the energy measures are calculated annually. This makes it impractical to have a monthly scorecard that examines the entire set of thirteen measures. With respect to the human resources measures, a committee composed of representatives from each CAA subsidiary meets monthly to consider the most recent results and plan actions. Frédérique Boulanger chairs this committee: 
"Our goal is to keep the spotlight on the CSR metrics. Its not just to look at the results but to ask what the subsidiaries involved are going to do to improve the situation."

Other measures are reviewed annually and the information from this analysis forms the basis in the upcoming two year plan.

\section{Carbon reduction initiative}

One of the more complex aspects of the SER activity at CAA to date relates to the initiative to reduce carbon generation. This initiative provides valuable insight on the use of management control mechanisms at CAA. One of the key goals of the CAA sustainability program is to limit the company's direct and indirect impact on the environment. In tackling this challenge, the SER team first needed to agree on how best to measure carbon generation. Only limited guidance exists for organisations wishing to measure environmental impact. For example, GRI proposes thirty indicators that relate to the environment, covering areas such as the use of materials, the consumption of energy and water, the impact of activities, the weight of greenhouse gasses emitted (CO2, NO, SO), spills and waste.

Among these indicators, most useful to the banking sector are GRI indicator EN 16, that covers reporting on all direct and indirect emissions in terms of $\mathrm{CO} 2$ equivalents, and Indicator EN 20, that covers other gasses (NO, SO). However these guidelines do not specify measurement practice, rather they recognise that different methodologies 
are available to calculate the amount of greenhouse gas emissions. Users are referred to the Greenhouse Gas Protocol Initiative (GHG Protocol) for compilation details. However this organisation provides some excel templates but does provide standards to allow constant reporting across entities.

Therefore any organisation wishing to measure emissions must first design the measure it will use. To obtain help in measuring carbon emissions, CASA turned to l'Agence de l'Environnement et de la Maîtrise de l'Energie (ADEME), the French environment and energy management agency. ADEME has devised a methodology for estimating the greenhouse gas (GHG) emissions generated by an activity. The ADEME method, known as "Bilan Carbone ${ }^{\circledR}$ ", provides specific guidance on how to measure the effect on $\mathrm{CO} 2$ emissions from a variety of sources.

ADEME worked with individual parts of CASA, including CAA, to prepare specific carbon analysis frameworks. The analysis of CAA operations identified direct and indirect greenhouse gas generation related to six main sources: inputs, travel, buildings, energy, freight and waste. The study estimated that CAA activities were responsible annually for approximately 21,000 tonnes of CO2 teq (International Toxic Equivalents). Broken down by source, inputs were responsible for the largest amount $(10,000$ tonnes) followed by travel and buildings (3,500 tonnes each) and energy (2,500 tonnes). The study also segregated these carbon emissions for each of the CAA business units. 
Following this analysis CAA was able to identify the areas where carbon reduction could be best achieved and to set targets. Using the general objectives set by the "Grenelle" (French government initiative) and the European Commission intermediate and long term targets were calculated to serve as references: to reduce $\mathrm{CO} 2$ to 17,000 tonnes by the year 2020 (Grenelle) and to 5000 tonnes per year by 2050 (EU). In addition a 24 month target, part of the 2010-12 plan, was set calling for the reduction of energy consumption by $10 \%$.

Setting the 24 month targets involved detailed analysis of the six main sources of GHG emissions for each of the CAA subsidiaries. To reduce $\mathrm{CO} 2$ generated through inputs, CAA looked at the processes that caused consumption of energy, such as paper use, and acquired services. For each of these, an internal analysis was conducted to identify factors that explain the causes of GHG emissions and to suggest solutions. Additional measures were then created within the categories and programs were launched. For example, to examine GHG related to purchased services, suppliers were first questioned concerning their processes. This was done primarily through a questionnaire, although some interviews were also conducted. Subsequently a purchasing code was created and a supplier certification process was initiated. A 24 month target was set to reduce GHG related to purchased services by 730 tonnes of $\mathrm{CO} 2$ teq.

With respect to the use of paper, a key generator of greenhouse gasses, an employee survey was used to examine paper use habits. Target reductions for the first 24 month 
period were set at $10 \%$ for office use and $15 \%$ for paper sent to customers. This represented a reduction of 342 tonnes of $\mathrm{CO} 2$ teq. To achieve these targets some processes related to photocopies were revised, including a requirement to print all documents on both sides and the replacement of colour printing with black and white. Printing of FAX was suppressed, the use of recycled paper was mandated and a program to encourage customers to received electronic information was launched. Paper use was further reduced through the installation of pooled multifunction photocopiers.

Travel is responsible for 3500 tonnes of equivalent CO2. Greenhouse gasses are primarily caused by employees travelling to and from work and to meetings. The ADEME study had surveyed employee travel and found that commuting created 2500 tonnes of $\mathrm{CO} 2$ per year and involved a high level of personal vehicle use. A two year target reduction of $10 \%$ was set and programmes were created, including encouragement for car pooling, creation of bicycle parking places at the office and an increase in subsidies for taking public transport. Reflexions have begun on the conditions needed to permit some working from home. Reductions were also targeted for professional travel, to be achieved through greater use of video-conferencing. To this end, employees were also surveyed concerning the frequency of their travel to business meetings and their current use of video-conferencing.

With respect to the use of buildings, a subsidiary of the Credit Agricole Group specialized in real estate management defined meaningful objectives through a very 
careful, building by building study, based on technical benchmarks. About half the $\mathrm{CO} 2$ generated in this area came from use of the information system. A two year target reduction of $17 \%$ was set, the achievement to come mainly for reducing the frequency of computer hardware replacement. As for energy use, the ADEME study revealed three main $\mathrm{CO} 2$ generators: electricity, purchased water for heating and air conditioning. Energy performance was then examined for all the main company locations and a two year target reduction of $10 \%$ was set.

Since the carbon initiative relies heavily on changing employee behaviour, a major employee communications program on $\mathrm{CO} 2$ was prepared. The centrepiece of the communications program was a short movie prepared for employees that explained the nature of the carbon project and the goals that had been set. Examples were presented of how employees could reduce carbon emissions and estimates were made on the financial impact to the company if energy costs were to increase and nothing was done to reduce consumption. A series of stickers were created and placed strategically to remind employees to turn off lights, computers and other energy using devices when not in use. Communication is now maintained regularly through a quarterly on-line newsletter sent to all employees. To facilitate ease of understanding, carbon reduction results are communicated to employees in terms of percentages rather that tonnes of $\mathrm{CO} 2$.

Contrary to the impression given in published literature, this initiative has also relied on boundary systems. For example, interrupters were installed on some electrical 
extension cords to limit consumption when equipment is not in use. Systems were installed that automatically extinguish some computers at day's end. Thermostats on heating and air conditioning were modified so that they engage and disengage automatically and temperatures were set at eco efficient levels $\left(19^{\circ} \mathrm{C}\right.$ in winter and $26^{\circ} \mathrm{C}$ in summer). Other programs include replacement of some heating equipment, improvements in building insulation, and the creation of environmentally based policies related to leasing. Environmentally driven policies were established that govern some new equipment acquisitions.

The carbon initiative has already achieved most of its short term goals. CO2 generation is on target and dropping. Paper use is down sharply. For one subsidiary, Predica, paper use has dropped from 49 million to 42 million pages annually, primarily through a reduction in the amount of paper sent to customers. Other achievements include a switch to the exclusive use of paper from eco-managed forests, use of lighter grades of paper, use of $100 \%$ recycled envelopes and environmental printers and sorting of waste in the offices to encourage recycling.

The current SER plan will end in 2012, but CAA is already working on the next phase. The 2012-2014 plan will include a very detailed global risks analysis and cartography of all stakeholders (NGOs, employees, shareholders, distribution networks, rating agencies, public authorities, etc.). This process is just beginning, but the assumption is that the new plan will include some projects that will make a significant impact on the 
core of the CAA business model: eco-design of products, interactions with retailers, transparency vis-à-vis NGOs with respect to areas such as product definitions, etc.

Another major change to be introduced in the system is the establishment of a clear connection between CSR goals and the incentives of top executives. As a result of a decision made by the Crédit Agricole Group, from 2012, one third of the bonus of the top executives will be based on SER metrics. For CAA, this involves the most senior ten executives. Bonus payment will be based on year over year improvements in the set of CSR metrics rather than on specific targets, so as to focus CSR activities on continuous improvement over a wide range.

CSR managers are happy with the progress made in the first two years. Brigitte Cachon observes:

"Our biggest satisfaction is that everyone is aware of the CSR program and can talk about the goals. We learned the importance of moving gradually. Before trying to get a large number of people involved we began with little projects such as collecting eyeglasses and toys. We didn't talk much about CSR at the beginning. Now that this is a success and CSR is an implanted value, we are ready to move on to the next level in which we involve more intensively our stakeholders, particularly our customers and consumer associations."

\section{Discussion}


Management control theory predicts that in executing strategy organizations will use a range of management control systems. Where strategy involves change, we expect to find management controls linked to the desired outcomes .On the other hand, we do not expect to find management control mechanisms for activities that are political in nature, designed to associate organizations with specific values rather than to affect internal change. A significant part of the sustainable development literature questions the intentions of organizations that report environmental and social achievements, arguing that the primary goals relate more to image management than to organizational change.

The approach to manage corporate social responsibility at Crédit Agricole Assurances provides a good example of an organisation that uses a range of management controls intensively in achieving its sustainability goals. The main control lever is the beliefs system. Management understands that the greatest results will come from the actions and ideas of employees. Communications therefore are aggressive, widespread, constant and varied. Employees are specifically brought into the execution of the CSR strategy. They receive continuous feedback from the company on the goals and achievements of the CRS initiative, their suggestions are sought and their voluntary participation is encouraged.

Measures play a major role. As the Bilan Carbone ${ }^{\circledR}$ example demonstrates, GHG emissions were measured globally for the whole company, but also locally for specific categories of waste and for business units. Annual carbon emissions were also 
estimated per employee and communicated to employees. Moreover in addition to measuring $\mathrm{CO} 2$ emissions, other sub-measures are created within this program related to travel, the use of paper and waste. Measures were prepared to calculate the use of heating fuel, electricity and natural gas on a daily basis and information was gathered from suppliers. While targets were set for the indicators, no direct connection was made between these targets and the incentive reward system. However, for the top ten managers, the bonus program will be revised in 2012 to include overall progress in SER.

Despite the primacy placed on changing employee attitudes, boundary system controls were also designed. Notably, administrative structures were created, that assigned full time and part time CSR roles, policies were established related to purchasing and paper use and physical constraints were implemented that reduce GHG emissions related heating and air conditioning and well as associated costs.

The presence of so much management control at CAA raises the question of the tradeoffs between cost and benefit within the program. Some initiatives clearly represent additional cost for the company. Senior managers have been assigned to CSR activities on a full time basis. Web sites have been constructed and are being maintained. Additional work has been incurred in investigating and vetting suppliers. Meetings are held regularly, training costs have increased and costs related to data collection activities have increased. 
Offsetting these costs however are significant economic savings. So far, the company has reduced paper use by 10 to $15 \%$ and switched to cheaper recycled paper. Heating and air conditioning costs have been reduced by a similar percentage. Work related travel has been reduced. CAA has not prepared a formal financial analysis of the costs and benefits of their CSR initiative to date. Nevertheless the considerable savings in energy and paper permit the conclusion that the activities have been at least costless.

It is nevertheless worth noting that reducing costs has never been seen as a first priority objective at CAA. As Frédérique Boulanger points out:

"It is not obvious that our approach to CSR has resulted in lower costs. It could have indeed generated more costs than returns. - at least for the short term - but short term cost reduction is not our central strategy. The key is to be coherent with what we claim. This will have a huge motivating impact and should be a real source of value creation as we move forward."

In addition to the consequences of the CSR program on the company itself, employees are also personally affected. Replacing vehicle commuting travel with other forms affects stress and overall health, both positively and negatively. Involvement in CSR planning, proposing initiatives, actively participating in philanthropic activities all serve to improve employee morale and commitment to the organization. 
A major step remains however in setting company policy related to socially responsible investments. Management at CAA has begun to address this subject, setting a target of one billion euro. The company has created financial products that include a focus on corporate responsibility and its portfolio of these CSR products is increasing. Remaining however is the decision of whether to deliberately limit investments in certain sectors or economies. So far CAA management has committed itself to action in this area, however action plans remain to be developed.

If embracing sustainability has been costless up to now, modifying investment criteria will introduce a different cost / benefit dynamic. The company will need to assess the positive and negative aspects associated and to craft a strategic plan that achieves benefits on all three sustainability axes - social, environmental and financial. This is a major part of the 2012-2014 CSR plan currently under construction.

A basic principle of sustainability is that organizations should not attempt to achieve financial goals while passing social and environmental costs on to others. Very little literature has been published on how organizations can achieve success in all three areas at once. The CAA case provides an example of how one organization uses management control mechanisms intensively to reduce environmental costs, increase social benefits and increase shareholder return simultaneously. However at CAA early success has been achieved partially because targeted areas have not been previously addressed. Future success will be more difficult to achieve and will be achieved more slowly. 
Table 1

\section{Crédit Agricole Assurances \\ Measures and targets for the 2010-12 plan}

\section{Factor}

\section{Environment}

Consumption of paper

in the office

Volume of paper sent

to customers

Energy consumption

\section{Human resources}

Handicapped

workforce

Feminization of

management:

Training for employees

over 45 years of age:

Employee satisfaction:

\section{Products and services}

Make socially

responsible

investments

Green products

offered

SRI

Customer satisfaction

\section{Solidarity}

Employee proposed solidarity projects

Solidarity projects

financed
Yes / No

Measure

kg/employee

sheets/customer)

$\mathrm{kWh} / \mathrm{m} 2$

$-10 \%$

Number of

employees

Percentage

Percentage

Percentage

Euro

Yes / No

Yes / No

Number of projects

10

Number of projects

$-10 \%$

$-15 \%$

$40 \%$

$80 \%$

$60 \%$

level

10
Target

$+50 \%$

At least once

One, at the

international

$100 \%$ of Yes
Prepared by CASA building management business unit (CA Immoblier)

Remark

An employee survey was used to examine paper use habits

The target is derived from an analysis of the current situation with the aim to define an objective that all units could achieve.

Based on an insurance sector benchmark (some units are below, others already above)

Encourage some units to include green products in their product range

All units should put some customer satisfaction measures in place

These two categories of projects get a 300.000 Euros budget per year 


\section{Bibliography}

Adams Carol and McNicholas Patty, Making a difference. Sustainability reporting, accountability and organisational change, Accounting, Auditing \& Accountability Journal, Volume 20, p. 382-402, (2007).

Albelda Perez, Esther, Ruiz, Correa Carmen and Fenech, Francisco Carrasco, Environmental management systems as an embedding mechanism: a research note, Accounting, Auditing \& Accountability Journal, Volume 20, p. $403-422$ (2007).

Andersen, Otto, Environmental reporting and transport - the case of a public transport company, Business Strategy and the Environment, Nov/Dec., p. 386-399 (2003).

Anthony, R. The Management Control Function, Harvard University Press, Cambridge, MA. (1988).

Barandas, Christian, Berland, Nicolas, and Siwertz, Nicolas, Responsabilité sociale: la méthode Areva, L'Expansion Management Revue, Hiver p. 106-117 (2007).

Branco, Manuel Castelo and Rodrigues, Lucia Lima, Communication of corporate social responsibility by Portuguese banks A legitimacy theory perspective, Corporate Communications: An International Journal, Volume 11, p 232-248(2006).

Burritt, R.L. and Saka, C., Environmental management accounting applications and ecoefficiency: case studies from Japan, Journal of Cleaner Production, Volume 14, p. 126275 (2006).

Chen, Stephen and Bouvain, Petra, Is Corporate Responsibility Converging? A Comparison of Corporate Responsibility Reporting in the USA, UK, Australia, and Germany Journal of Business Ethics, Volume 8, p. 299-317 (2009)

Crawford, Elise Perrault and Williams, Cynthia Clark, Should corporate social reporting be voluntary or mandatory? Evidence from the banking sector in France and the United States, Corporate Governance, Volume 10, p. 512-526 (2010).

Cuesta-Gonzalez, Marta de la, Munoz-Torres, Marıa Jesus and Fernandez-Izquierdo Marla Angeles, Analysis of Social Performance in the Spanish Financial Industry Through Public Data A Proposal Journal of Business Ethics, Volume 69, p. 289-304 (2006).

Douglas, Alex, Doris, John and Johnson, Brian, Corporate social reporting in Irish financial institutions, TQM Journal, Volume 16, p. 387 (2004).

Durden, C., Towards a socially responsible management control system, Accounting, Auditing \& Accountability Journal, Volume 21, p. 671-94 (2007). 
Enquist, Bo, Johnson, Mikael and Skålén, Per, Adoption of corporate social responsibility - incorporating a stakeholder perspective, Qualitative Research in Accounting \& Management, Volume 3, p. 188-207 (2006).

Epstein Marc J. and Roy Marie-Josée, Sustainability in Action: Identifying and Measuring the Key Performance Drivers, Long Range Planning, Volume 34, p. 585-604 (2001).

Ferreira, Aldonio, Moulang, Carly and Hendro Bayu, Environmental management accounting and innovation: an exploratory analysis, Accounting, Auditing \& Accountability Journal, Volume 23, p. 920-948 (2010).

Gates, Stephen and Germain, Christophe, Integrating Sustainability Measures into Strategic Performance Measurement Systems: An Empirical Study, Management Accounting Quarterly, Volume 11, p. 1-7 (2010).

Gray, R. H. Does sustainability reporting improve corporate behaviour? Wrong question? Right time?, Accounting and Business Research, International Accounting Policy Forum, p.65-88 (2006).

Henri, Jean Francois and Journault, Marc, Environmental performance indicators: An empirical study of Canadian manufacturing firms, Journal of Environmental Management, Volume 87 p.165-176 (2008).

Henri, Jean Francois and Journault, Marc, Eco-control: The influence of management control systems on environmental and economic performance. Accounting, Organizations and Society, Volume 35, p.63-80 (2010).

Humphreys, Michael and Brown, Andrew D., An Analysis of Corporate Social Responsibility at Credit Line: A Narrative Approach, Journal of Business Ethics, Volume 80, p.403-418 (2007).

Ilinitch, Anne Y., Soderstrom, Naomi S., and Thomas Tom E., Measuring corporate environmental Performance, Journal of Accounting and Public Policy, Volume 17, p. 383-408 (1998).

Kaplan, R., Norton, D., The Balanced Scorecard-Measures That Drive Performance, Harvard Business Review Volume 70, Jan.-Feb., p.71-79 (1992).

Keating, Byron, Quazi, Ali, Kriz, Anton, Coltman, Tim, In pursuit of a sustainable supply chain: insights from Westpac Banking Corporation, Supply Chain Management: An International Journal, Volume 13, p.175-179 (2008). 
Masanet-Llodra, M., Environmental management accounting: a case study research on innovative strategy, Journal of Business Ethics, Volume 68 no. 4, p. 393-408 (2006).

Melnyk Steven A., Sroufe Robert P. and Calantone, Roger, Assessing the impact of environmental management systems on corporate and environmental performance, Journal of Operations Management, Volume 21, p.329-351 (2003).

Morsing, Mette, Oswald, Dennis, Sustainable leadership: management control systems and organizational culture in Novo Nordisk A/S, Corporate Governance, Volume 9, p.83-99 (2009).

Norris, Gweneth and O'Dwyer Brendon, Motivating socially responsive decision making: the operation of management controls in a socially responsive organization, The British Accounting Review, Volume 36 p.173-196 (2004).

Pedersen, Ebsen Rahbek and Neergaard, Peter, From periphery to center: how CSR is integrated in mainstream performance management frameworks, Measuring Business Excellence, Volume 12, p. 4-12 (2008).

Riccaboni Angelo and Leone Emilia Luisa, Implementing strategies through management control systems: the case of sustainability, International Journal of Productivity and Performance Management, Volume 59, p. 130-144 (2009).

Sherman W Richard and DiGuilio Lauren, The Second Round of G3 Reports: Is Triple Bottom Line Reporting Becoming More Comparable?, Journal of Business \& Economics Research, Volume 8, p. 59-77 (2010).

Simons, R., Accounting control systems and business strategy: An empirical analysis, Accounting, Organizations and Society, Volume 12, p.357-374 (1987).

Simons, R., Levers of control: How managers use innovative control systems to drive strategic renewal, Boston, Harvard Business School Press (1995).

Spence, Laura and Bourlakis, Michael, The evolution from corporate social responsibility to supply chain responsibility: the case of Waitrose, Supply Chain Management: An International Journal, Volume 14, p.291-302 (2009).

Weber Olaf, Sustainability Benchmarking of European Banks and Financial Service Organizations, Corporate Social Responsibility and Environmental, Volume 12, p.73-87 (2005).

Yin, Haitao and Schmeidler, Peter J., Why do standardized ISO 14001 environmental management systems lead to heterogeneous environmental outcomes? Business Strategy and the Environment, Volume 18, p 469-486 (2009). 
ESSEC Business School Avenue Bernard Hirsch BP 50105

95021 Cergy-Pontoise Cedex France

Tél. +33(0)134433000

$\mathrm{Fax}+33(0) 134433001$

www.essec.fr

\section{ESSEC Executive Education}

CNIT BP 230

92053 Paris-La Défense

France

Tél. +33(0)146924900

Fax +33(0)1 46924990

http:l/formation.essec.fr

ESSEC Business School

Singapore Campus

100 Victoria Street

National Library Building \# 13-02

Singapore 188064

essecasia@essec.fr

Tél. +6568849780

Fax +6568849781

www.essec.edu

\section{Informations}

Alison Bougi

+33 (0)134433358

bougi@essec.edu

unw.essec.fr

research.center@essec.fr

ISSN 1291-9616 